\title{
Literatura e Religião nas obras Adeus às Armas e Olhai os Lírios do Campo
}

\author{
Literature and Religion in Works A Farewell to Arms and Look at the Lilies of the \\ Field
}

Maria Angélica F. Jurity Martins ${ }^{1}$

Presley Henrique Martins²

\begin{abstract}
Resumo: o artigo busca analisar a relação entre religião e literatura, a partir da interpretação das obras Adeus às Armas, de Ernest Hemingway e Olhai os Lírios do Campo, de Érico Veríssimo. Para alcançar o objetivo proposto, num primeiro momento, o texto procura estabelecer a base metodológica que possibilita o estudo entre religião e literatura. A partir do esclarecimento do método teo-antropológico, o artigo analisa as obras Adeus ás Armas e Olhai os Lírios do Campo e procura mostrar como a questão de Deus é pensada nessas obras, publicadas em contextos próximos.

Palavras-chave: Religião; Literatura; Hemingway; Érico Veríssimo.

Abstract: the article seeks to analyze the relationship between religion and literature, based on the interpretationof $A$ Farewell to Arms, by Ernest Hemingway and Look at the Lilies of the Field, by Érico Veríssimo. To achieve the proposed objective, at first, the text seeks to establish the methodological basis that enables the study between religion and literature. Based on the clarification of the anthropological method, the article analyzes the works $A$ Farewell to Arms and Look at the Lilies of the Field and tries to show how the question of God is thought of in these works, published in close contexts.
\end{abstract}

Keywords: Religion; Literature; Hemingway; Érico Veríssimo.

\section{Introdução}

Propomos estabelecer neste artigo o diálogo entre Literatura e Religião, uma vez que possuem uma interrelação bastante notável quando observamos que a teologia das grandes religiões - judaísmo, cristianismo e islamismo - têm a palavra como fonte de revelação (BINGEMER, 2015). Não somente a literatura, de maneira geral, reflete as experiências humanas; tratando-se do cristianismo, a Bíblia é um "Livro da Vida por excelência” (BINGEMER, 2015, p. 19). Nesse sentido, o diálogo entre essas duas áreas do conhecimento enriquece e amplia nossa compreensão de mundo. Somente a partir da segunda metade do século XX (CAPELLI, 2017), no entanto, que se estabeleceu essa interdisciplinaridade com os estudos de teopoética.

1Licenciada em Ciências Sociais pela PUC-Campinas e mestranda em Ciências da Religião pela mesma instituição. E-mail: angelicajurity@gmail.com

2Licenciado em Filosofia pela PUC-Campinas e mestrando em Ciências da Religião pela mesma instituição. E-mail: presley.hmartins@gmail.com 


\section{SACRILEGENS

Segundo SILVEIRA (2019), o termo teopoética tem dois sentidos: para se referir ao campo de pesquisas que se voltam às interfaces entre religião e literatura, e para apontar um modo de se fazer teologia. No segundo sentido, Capelli (2011), assinala que não há um único método, uma vez que esse é selecionado de acordo com o objeto de análise:

A metodologia, portanto, tem o papel de proporcionar um princípio, uma espécie de «fio de Ariadne» que conduz o trabalho para não cair em contradição, que ajuda a explicar como a literatura pode refletir a questão de Deus e como a teologia pode ajudar a pensar a literatura (CAPELLI, 2017, p. 66).

Quando nos aprofundamos às pesquisas na área, percebemos que essas, embora adotem métodos diversificados, como apontado por Capelli, se restringem ao campo teológico. Dessa forma, existe "uma carência epistemológica e metodológica para trabalharmos sob o viés das Ciências da Religião nas buscas de interfaces entre literatura e religião" (SILVEIRA, 2019, p. 140). Essa carência deve-se ao fato que a própria constituição da área é ainda recente. O primeiro sentido, do qual fala Silveira (2019), pode ser aprofundado se desenvolvermos métodos de pesquisas em teopoéticas a partir das Ciências da Religião. Assim, como a própria autora aponta, se faz necessário discussões epistemológicas e metodológicas pelos cientistas da religião.

Estabelecer o diálogo entre literatura e religião a partir das Ciências da Religião não é, no entanto, tornar improfícua a relação com a teologia, mas percebêla como uma das possibilidades no que se refere ao método, e, ainda sim, partir do pressuposto que a literatura, dado sua constituição autônoma e expressão vívida, não deve ser utilizada para encaixar-se num conceito teológico, mas, a partir dela e, em conjunto com a teologia, refletir sobre a experiência humana e permitir que essa experiência também provoque a elaboração teológica.

No que se refere à estrutura desta proposta, dividimos em três seções: na primeira apresentaremos o método teo-antropológico como uma possibilidade de diálogo entre literatura e religião, apontando para as principais discussões em relação ao tema. Na segunda seção, faremos uma análise interpretativa da obra Adeus às armas, de Ernest Hemingway, e na terceira de Olhai os Lírios do Campo, de Érico Veríssimo. Em ambas as análises, pretendemos destacar o método teo-antropológico, sem, no entanto, abrir mão dos conceitos teológicos que podem lançar luz aos nossos objetos de estudo. 


\section{SACRILEGENS

\section{Método Teo-Antropológico Como Possibilidade No Diálogo Entre} Teologia E Literatura

O grande problema que enfrentamos quando falamos sobre o diálogo entre teologia e literatura refere-se ao método. O método deve nos orientar para justificação de um estudo específico. Isto significa dizer que a teologia não pode se sobrepor à literatura; no sentido, por exemplo, de submeter a literatura ao espectro teológico e buscar, nas obras literárias, exemplos das narrativas bíblicas. Portanto, o método necessita estabelecer o diálogo entre as áreas e, a partir da especificidade do estudo, obter um conhecimento próprio que não seja somente teológico ou literário. Nesse sentido, Alex Villas Boas, em seu texto O Método Antropológico no diálogo entre Teologia e Literatura em Antônio Manzatto, busca refletir sobre esse problema. Villas Boas realiza um movimento dialético em seu texto, cuja exposição consiste na contextualização da crítica feita por Antônio Magalhães ao método teoantropológico3 de Manzatto. Ao buscar as influências e as raízes da metodologia de Manzatto, Villas Boas recupera a perspectiva das principais características do método teo-antropológico, que, por sua vez, afasta-se da crítica realizada por Antônio Magalhães. Operando desta forma, acompanhamos o contexto do debate sobre o método. Deste modo, compreendemos o método teo-antropológico, na medida em que se responde às críticas realizadas ao próprio método.

Antonio Manzatto (VILLAS BOAS, 2020) publica, em 1994, sua leitura teológica da literatura. Este trabalho foi desenvolvido entre 1988 e 1993 no contexto de uma época propícia ao diálogo. "O objeto de investigação do teólogo brasileiro é o romance Tenda dos Milagres de Jorge Amado, obra publicada em 1969, que na ocasião já gozava de renome internacional” (VILLAS BOAS, 2020, p. 27). A obra de Jorge Amado foi traduzida em muitos países. O contexto da publicação de Manzatto se insere na discussão a respeito da crise da linguagem teológica. Nesse sentido, a obra de Manzatto ganha notoriedade, pois inaugura um campo de pesquisa ainda não explorado no meio acadêmico brasileiro.

O debate epistemológico terá início com Antônio Carlos Magalhães, que na obra Deus nos Espelhos das Palavras, publicada em 2000, revisitará a obra de Manzatto de forma crítica (VILLAS BOAS, 2020). "Em sua obra Magalhães

\footnotetext{
3 Embora no texto de Alex Villas Boas ele utilize o termo antropológico, optamos, doravante, utilizar o
} termo teo-antropológico para caracterizar a especificidade do estudo. 


\section{SACRILEGENS

apresenta uma compilação dos métodos utilizados nos dois polos epistemológicos, teologia e literatura, e propõe o que chama de método de correspondência” (VILLAS BOAS, 2020, p. 27). Magalhães desenvolve o método de correspondência a partir da Teologia da Cultura de Paul Tillich e o método de correção de Karl-Joseph Kuschel. Da Teologia da cultura, Magalhães faz a diferenciação entre o teólogo da cultura e o teólogo da igreja. O primeiro, apesar de buscar na tradição eclesiástica as referências para a sistematização teológica, não restringe sua reflexão a algo eclesial.

De Kuschel, tem como ponto de partida o "método de análise estrutural", de "correlação" e "confrontação" que procura "assumir semelhanças" (analogia) e "definir diferenças" Pois uma dinâmica pressuposta entre pergunta e resposta para o autor precisa ser "radicalmente superada", e por isso a proposta pensar a relação entre teologia e literatura desde a correspondência (VILLASBOAS, 2020, p. 28).

A partir dos pressupostos presentes no método de correspondência, Magalhães traçará sua crítica a Manzatto. Nesse sentido, Magalhães interpreta a obra de Manzatto a partir da relação da pergunta e resposta e da teologia eclesial (oposta à teologia da cultura apropriada por Magalhães). Portanto, tanto a relação da pergunta e resposta, quanto a teologia eclesial, são opostas ao método de correspondência. A prática pergunta e resposta consiste em fazer perguntas à literatura sobre as quais a teologia já tem as respostas, ou seja, a investigação aqui consiste em buscar na literatura o que a teologia já responde. Ao proceder dessa forma, não se encontra nenhum conhecimento novo sobre a interpretação de Deus. Portanto, Magalhães critica a abordagem de Manzatto na esfera da teologia católica (VILLAS BOAS, 2020), com a qual Manzatto teria uma implícita relação com a teologia normativa da instituição eclesial em questão. Segundo Villas Boas, proceder deste modo teria como consequência:

\footnotetext{
1) a revelação de Deus é já "definida" e "delimitada", o que resulta numa teologia com respostas prontas; 2) a literatura como mera "pergunta antropológica", está incapacitada de provocar "mudanças significativas na reelaboração de nossas visões de Deus" e; 3) o método de aproximação da teologia com a literatura, se dá com a dinâmica "pergunta" (literatura) "resposta" (teologia) (VILLASBOAS, 2020, p. 29) .
}

Em contraposição às consequências de uma abordagem a partir da teologia eclesial, Magalhães adotará uma proposta voltada para leitura teológica na obra literária, cuja obra literária aborda temas que são religiosos, "sendo ela mesma fonte 


\section{SACRILEGENS

de revelação. Deste modo, entende o autor, que tal perspectiva é capaz de superar a relação de ‘instrumentalização’ da literatura” (VILLAS BOAS, 2020, p. 20). Assim, a teologia que se utiliza da literatura como instrumento, "reduz a Revelação a um ‘depósito de respostas prontas' ao dilema humano” (VILLAS BOAS, 2020, p. 20). No entanto, Villas Boas elucidará que a crítica a Manzatto não corresponde ao método operado pelo próprio Manzatto. Ele se perguntará se a categoria pergunta e resposta, a qual Magalhães critica, "coincide com a prática social de antimodernismo ou diz respeito a outra perspectiva" (VILLAS BOAS, 2020, p.33). Para iluminar a questão, Villas Boas se aprofundará nas influências do pensamento de Manzatto.

Ao contextualizar a crise da linguagem, Villas Boas (2020) menciona que Paul Ricoeur (1913-2007) foi uma das grandes pontes do diálogo entre os estruturalistas e a fenomenologia, que estavam no debate sobre a crise da linguagem, cuja perspectiva estruturalista diz que a existência de algo consiste na palavra que descreve a realidade. Nesse contexto, o discurso teológico especulativo entra em crise. No entanto, Paul Ricouer aponta que a função poética da linguagem é entendida como órganon do discurso religioso. Deste modo, a saída da crise se volta para função poética da linguagem que, sendo a estrutura do discurso religioso, estabelece uma possível relação entre a teologia e a literatura.

Karl Rahner foi uma das grandes influências teológicas no trabalho de Antônio Manzatto. Segundo a teologia de Rahner "toda teologia é certamente e sempre teologia que nasce das antropologias não necessariamente religiosas [profanen Antropologien] e interpretações próprias do ser humano” (RAHNER apud VILLAS BOAS, 2020, p. 33). Aqui está, portanto, um elemento importante para nossa compreensão do método de Manzatto, pois o olhar se volta primeiramente para o humano e, nesse sentido, nenhuma resposta preestabelecida pode responder o que está em acontecimento. Posto isto, a teologia, doravante, deverá acompanhar o fato do mundo, suas condições fácticas e sofrimentos reais.

Outro teólogo importante que influenciou Antônio Manzatto foi Adolphe Gesché (1928-2003), teólogo belga e orientador de tese de Manzatto. Gesché “adota um exercício de ressignificação da linguagem teológica procurando sintonizar um novo modo de pensar a questão de Deus [Dieu pour penser] desde o papel que a teologia exerce na busca de sentido na cultura contemporânea" (VILLAS BOAS, 2020, p. 34). Nesse sentido, Villas Boas conclui que a perspectiva teológica de Manzatto é rahneriana, pois o teo-antropológico é visto como da Revelação. Mas, ao 


\section{SACRILEGENS

mesmo tempo, é gescheriana, pois o ser humano é também lugar de revelação, ou ainda, um "espaço de revelação e afirmação do humano" (VILLAS BOAS, 2020, p. 35). Assim, a revelação também ocorreria por meio da literatura já que se trata de um meio pelo qual o ser humano se manifesta. Portanto, conclui Villas Boas:

[...] Manzatto estaria mais próximo de uma passagem para uma teologia da cultura aos moldes do que diz Magalhães, do que legitimar um viés ideológico. Manzatto, sobretudo, insere a aproximação da teologia com a literatura dentro do universo da TDL [Teologia da Libertação], ao assumir o método de ver-julgar-agir, de manter a preocupação econômica e todas as suas derivações alinhadas à questão antropológica (VILLAS BOAS, 2002, p. 37).

Assim, nessa perspectiva, a literatura é análise, é ver a partir de um determinado contexto. Nesse sentido, quando Manzatto realiza um estudo sobre a obra de Jorge Amado, Manzatto procura na antropologia contida na obra amadiana uma reflexão qualitativa do ser humano concreto, que vive a realidade singular latino-americana de brasileiro, subdesenvolvido, com seus complexos sociais e sua forma condicionada, mas que busca libertação (VILLAS BOAS, 2020). Deste modo, a literatura não é apenas um questionamento teo-antropológico, "mas tem um lugar privilegiado na sociedade como fonte reveladora da realidade antropológica, à medida que apresenta uma compreensão do que significa ser humano no mundo" (MANZATTO apud VILLAS BOAS, 2020, p. 37).

O que significa ser humano no mundo é interpretado a partir do contexto, da situação. Quando Manzatto se interessa pela obra de Jorge Amado, está interessado na revelação antropológica presente na obra, é exatamente essa situação específica que se revela o teo-antropológico, em que acontece a experiência com Deus, não submetida à teologia especulativa, de tal forma que essa experiência é totalmente nova e única, o que torna a reflexão teológica, sobre essa experiência, mais dinâmica e atual. A literatura atinge a realidade como relato de uma experiência interna e intensa, a partir do homem situado e contextualizado, não descreve nem interpreta, mas representa a realidade, captando o radicalmente teo-antropológico da experiência vivida da condição humana. Desse modo, "o que a literatura oferece de pertinente à teologia é seu caráter antropocêntrico, em que se dá a experiência de Deus e a partir de onde se inicia a reflexão teológica” (VILLAS BOAS, 2020, p. 41). Portanto, a reflexão teológica sempre vem depois da experiência, e a literatura é retrato da experiência humana, que sempre se mostra diferente dependo de cada 


\section{SACRILEGENS

época e situação. É a partir dessa perspectiva que daremos continuidade à nossa proposta.

\section{Análise da obra "adeus às armas, de Ernest Hemingway"}

Segundo o método teo-antropológico de Antônio Manzatto, a literatura é fonte reveladora da antropologia e proporciona uma compreensão sobre o ser humano no mundo em seu contexto. Nesse sentido, a experiência humana retratada na obra literária reflete o espírito pelo qual a reflexão teológica deve ser orientada. Assim, pode significar pensar sobre a questão de Deus em uma determinada circunstância e, ao falar de circunstâncias, falamos de situações e acontecimentos aleatórios e experiências singulares, o que significa, por sua vez, falar de Deus sempre de modos diferentes.

Portanto, o contexto é muito importante para expressar essa experiência. É neste ponto que buscamos na obra "Adeus às armas" elementos que, partir do contexto devastador da primeira grande guerra, nos faz questionar sobre o pensamento acerca da religião em um contexto niilista - provocado pela própria guerra - presente no romance. A pergunta sobre como podemos interpretar a religião em um contexto aparentemente avesso às questões religiosas, coloca-nos no caminho de uma compreensão sobre a questão de Deus distante de uma teologia eclesial, justamente porque o horizonte em que nos encontramos é a falta de sentido e da impossibilidade da existência de um Deus em um contexto totalmente violento e perverso.

Adeus às Armas é o segundo romance do escritor norte-americano Ernest Hemingway, que foi publicado em 1929. É considerado como um romance autobiográfico, pois, em 1918, ferido em combate, Ernest Hemingway é internado em um hospital em Milão, onde conhece a enfermeira Agnes von Kurowsky, por quem se apaixona. Porém, ela não aceita casar-se com Hemingway, deixando-o profundamente desiludido. A rejeição de Agnes foi a grande desilusão amorosa da vida de Hemingway. O livro tem como tema central a paixão de Frederic Henry - que se alista no exército italiano como motorista de ambulância - pela enfermeira Catherine Barkley. Portanto no romance temos o mesmo pano de fundo que a experiência de Hemingway, pois também Henry se apaixona por Catherine quando está internado em um hospital após ser ferido em combate. Contudo, na obra, Henry 


\section{SACRILEGENS

não é rejeitado, vive uma paixão intensa com Catherine. No entanto, a dor vivida pelo protagonista do romance é análoga a de Hemingway, pois quando Henry deserta do exército para ficarem juntos, Catherine fica grávida e encontram nos alpes suíços o verdadeiro paraíso capaz de manter acesa a chama de seu romance, algo duradouro que fazem ambos se aproximarem de uma eternidade possível. Mas vivem no tempo e no seio de uma dilaceração cega e indiferente, e Catherine, durante o parto, perde o bebê e morre na mesa de cirurgia. Um acontecimento fatal. Henry, caminhando sob chuva, encerra o romance que nos leva da guerra ao paraíso e, inevitavelmente, novamente à guerra, só que agora travada na alma que irá tentar sobreviver em sua solidão, carregada por uma perda irreparável e de um amor irrepetível.

\footnotetext{
Porque, com efeito, trata-se aqui de um drama sobre o qual paira a indiferença do mundo. Frederic Henry e Catherine, em dado momento, acreditaram poder se isolar em seu amor, simplesmente se afastando da guerra, da matança disseminada. No entanto - e é ao que se chega, no final da leitura - , não há paraíso que se contraponha de fato ao inferno da guerra. A carnificina da guerra, que explicita a aleatoriedade da morte, é, aqui, apenas uma expressão mais drástica de uma brutalidade inerente à vida (AGUIAR, 2013, p. 9)
}

Diante dessa brutalidade inerente à vida, que se manifesta no contexto de guerra, de insegurança causada por mortes abruptas e lutos constantes, a religião é expressa a partir do niilismo. Henry narra com dureza o dilaceramento humano e a falta de esperança em um mundo que se consome em violência. Percebemos que qualquer esperança não passa de devaneio ou uma miragem que desaparece ao revelar a crueldade manifesta no decorrer da narrativa, que, às vezes, mesmo que o sofrimento pareça estar ausente - por exemplo, durante o romance dos protagonistas -, está a todo momento presente: “a carnificina da guerra, que explicita a aleatoriedade da morte, é, aqui, apenas a expressão drástica de uma brutalidade inerente à vida " (AGUIAR, 2013, p. 9).

Nesse sentido, o niilismo se aproxima do pessimismo do filósofo francês Emil Cioran (1911 - 1995), cujo pensamento diz: "A morte se espalha tanto, ocupa tanto lugar, que não sabemos mais onde morrer" (CIORAN, 2011, p. 13), é a força mórbida presente na atmosfera de Adeus às Armas, em que a realidade esmaga o sonho e a morte está sempre iminente. Esse curso decompositor da vida nadifica qualquer construção e possibilidade de sentido. Segundo Cioran: "Muito antes da física e da psicologia nascerem, a dor desintegrava a matéria e a angústia a alma” (CIORAN, 2011, p. 11). 


\section{SACRILEGENS

A guerra, na perspectiva do protagonista, não deixa saída, pois a dor e a perda não estão presentes somente nos campos de batalha - onde ganham sua maior expressividade - mas é constitutivo da vida, e, nesse sentido, é algo que não se pode dizer adeus. Acontece, porém, que os protagonistas acreditam que podem se isolar em seu amor simplesmente afastando-se da guerra. $O$ amor como apresenta o romance é essencialmente religioso. Esta afirmação é proferida pelo padre, amigo de Henry, quando este se apaixona por Catherine, o padre diz que: "O amor é um sentimento religioso".

- Quem sabe algum dia me torne um devoto. Mas, independentemente disso,rezarei pelo senhor conde. (Henry)

- Sempre quis tornar-me religioso como toda a gente de minha família.

Pena, não consegui. (Padre)

- É cedo ainda, conde. (Henry)

- Ou muito tarde. Talvez eu já tenha passado além do período religioso.

(Padre)

- Minha religião é noturna. (Henry)

- Quer dizer que está amando. Não esqueça que é um sentimento religioso.

(Padre) (HEMINGWAY, 2013, p. 198)

O rapaz americano, por ocasião da Grande Guerra se alistou como voluntário na linha de frente italiana e ferido recebe cuidados no hospital em Milão, apaixona-se perdidamente por Catherine, sua enfermeira. Encontra, no amor, o sentido de todo o aniquilamento e uma saída da guerra. Só um sentimento que, por ser um sentimento religioso, pode transcender toda a falta de sentido, mesmo que seja por um breve instante. $\mathrm{O}$ amor se mostra no texto como um sentimento religioso porque é o único sentimento que pode respirar sob escombros, que pode fazer com que sobrevivamos na dor e, de alguma forma, fazer com que toda a brutalidade da vida, a morte e o desaparecimento da existência, sejam menos importantes do que aquilo que se ganhou no amor: a possibilidade de viver diante da morte, mesmo que essa vida seja constituída por um sofrimento que a destrói.

Após conhecer Catherine e se recuperar no hospital, Henry volta à frente de batalha, onde acontece o desastre de Caporetto. De um lado, o horror dessa derrocada, de outro lado a saudade de sua amada Catherine. Surge então a dúvida: tem o direito de sacrificar sua felicidade em nome dessa guerra sem sentido que se transforma em derrota? Não seria muito mais honroso unir-se com aquela que ele engravidou? (Aguiar, 2013). Foge da linha de frente, deserta e se refugia na Suíça com Catherine. O paraíso encontra-se ao lado dela. Tem o lar que foi construído pelo amor de ambos. Mas a felicidade e o paraíso não passam de um sonho absurdo, lembrando 


\section{SACRILEGENS

mais um aforismo do filósofo francês: "Todo pensamento deveria se lembrar da ruína de um sorriso" (CIORAN, 2011, p. 9).

Vemos na própria vida de Hemingway e no momento histórico em que se passa a narrativa, o significado da expressão religiosa nesse contexto, escrito por um autor que presenciou a guerra. $\mathrm{O}$ amor que é a condição para o sentido nasce de uma exterioridade niilista onde mais nada pode crescer, pois, embora o amor apresenta-se como refúgio no interior da guerra, a própria guerra não pode ser abandonada, ela os persegue; deste modo, esse mesmo amor pode ser perdido pela aleatoriedade da morte, mas eles tentam salvar o que podem; porém, é nesta condição que, sendo o amor um sentimento religioso, é o que resisti e sempre nasce diante de um mundo abandonado pela bondade divina. Abandonado, pois não podemos nos relacionar mais com Deus a partir de um otimismo iluminista e do progresso. A violência ocorre de forma imprevista; no que controlamos e não podemos controlar, o que é próprio da vida nos acontecimentos aleatórios. Mas, de um modo paradoxal, a bondade ainda se revela nas ações e na construção de um paraíso que sempre se encontra e se perde no amor, lembrando a famosa frase de Hölderlin: "Mas onde há perigo, cresce também a salvação" (HEIDEGGER apud HÖLDERLIN, 2007, p. 391).O amor sobrevive porque é o que movimenta e possibilita - em um mundo em que a esperança parece estar desaparecida - uma ação de bondade. Quando toda vida se apresenta como cruel e cega, manifestando a indiferença que podemos sentir na própria natureza; quando o mundo parece estar avesso à presença de um ser bom onde razão não vê razões -, somente esse sentimento de amor, tão aleatório quanto a morte, pode mover o ser humano a encontrar, no aniquilamento, sua salvação perdida.

Podemos estabelecer um paralelo com o filósofo dinamarquês Søren Aabye Kierkegaard (1813-1855), a fim de elucidar o modo como a religião está sendo pensada, ou seja, não a partir da instituição, mas tendo como princípio a existência. Segundo Jon Stewart (2017), Kierkegaard, colocando-se como crítico da Igreja luterana da Dinamarca de sua época, dos sistemas filosóficos que esquecem os problemas concretos singulares da vida, vemos, na obra de Kierkegaard, o problema de "Deus" que se estabelece na perspectiva da experiência, que está além da instituição, da racionalidade e da lógica.

Deste modo, Kierkegaard fala de um Deus além da razão, um Deus do paradoxo, da contradição, e que se coloca em movimento na existência. Nesse 


\section{SACRILEGENS

sentido, Deus é inapreensível e inefável. A finitude do homem coloca-o em uma infinita diferença diante da eternidade transcendente. Deste modo, o homem defronta-se com sua própria má sorte e falta de sentido; sendo que não poderá haver sentido na certeza de um argumento lógico sobre a existência de Deus. Portanto, de modo análogo, a existência de Deus, no contexto do cenário de Adeus às Armas, também não pode ser apreendida pela razão, muito menos nas atrocidades provocadas pela guerra, pelo contrário, foi o progresso, a partir da razão, que levou a esse estado de calamidade.

Por fim, concluímos esta análise citando uma passagem de Adeus às Armas:

Aos que trazem coragem a este mundo, o mundo precisa quebrá-los, para conseguir eliminá-los, e é o que faz. O mundo os quebra, a todos; no entanto, muitos deles tornam-se mais fortes justamente no ponto onde foram quebrados. Então, aos que não se deixam quebrar, o mundo os mata (HEMINGWAY, 2013, p. 188)

É preciso quebrar para se tornar forte no ponto em que foi quebrado. É preciso que a religião quebre, que a estrutura dogmática e ortodoxa se dilua, que o sentido se desfaça, para que possamos descobrir e encontrar esse amor que existe e é obliterado. Esse amor não acaba quando as condições mudam, sobrevive no sofrimento e floresce em terras inférteis, onde mais nada parece brotar. Portanto, a antropologia presente no romance de Hemingway expressa a condição e também o espírito de uma época, ao mesmo tempo, proporciona uma nova relação entre o homem dilacerado e Deus. A reflexão sobre Deus emana da experiência concreta e contextualizada. Nesta obra podemos ver que o elemento religioso está presente no amor, e é neste amor que Deus sobrevive. Essa experiência é vivenciada no "escuro", o único momento quando Henry diz ser religioso, pois, à luz do dia, o mundo está imerso em guerra e sangue, mas no silêncio, na ausência de luz e na solidão, o religioso aparece quando os olhos estão fechados e vê somente no amor o que não pôde ser encontrado à luz do dia; o momento em que só pode ser visto a carnificina e a gratuidade da morte.

\section{Análise Da Obra Olhais Os Lúrios Do Campo, De Érico Veríssimo}

Busca-se nesta análise traçar uma intersecção entre religião e literatura, apropriando-se não somente do saber teológico, mas também do saber teoantropológico, com o objetivo de preservar a autonomia da obra literária. Trata-se, portanto, de pensar a religiosidade não como campo privilegiado da religião 


\section{SACRILEGENS

enquanto instituição, mas como experiência humana, podendo ser vivenciada na constituição do indivíduo e sua relação com o outro. Embora Olhai os Lírios do Campo apresente um discurso religioso, de vertente cristã, como seu próprio título anuncia, percebe-se que o objetivo da obra não é apropriar-se de conceitos teológicos para se pensar a realidade humana, mas antes propor que temas como busca pelo sentido de vida, transformação e esperança, ainda que articulados dentro do discurso normativo, manifestam-se na trajetória existencial de cada um, de modo que se possa pensar numa religiosidade ou, se preferirmos, numa espiritualidade aberta e muito mais orgânica, cabendo-nos também uma reinterpretação de passagens sagradas, tal como a que se apresenta na obra, a partir da concretude da vida e seu ímpeto integrador.

Trata-se, nesse sentido, não de lançar mão do saber teológico, uma vez que esse oferece às Ciências da Religião uma reflexão especializada da tradição religiosa (SOARES, 2007), mas de, a partir da Ciências da Religião, se obter um conhecimento mais lapidado, que possa servir para suscitar reflexões à espiritualidade vivenciada por cada indivíduo. Assim, o que se pretende a seguir é interpretar a religiosidade presente na obra de Érico Veríssimo, privilegiando seus aspectos teo-antropológicos, a partir dos quais podemos pensar a espiritualidade de maneira mais fluída e orgânica, dialogando com conceitos teológicos, como a coragem de ser, de Paul Tillich.

Érico Veríssimo é um dos grandes expoentes da literatura modernista no Brasil, tendo sido consagrado definitivamente pelo público-leitor a partir da publicação da obra Olhai os Lírios do Campo em 1938, a qual rendeu numerosas edições. O romance atraiu muitas críticas, sendo boa parte delas desfavoráveis ao autor, que também não tinha muita estima pelo que fora produzido. No prefácio de 1966 escreveu: "Acho-o [o romance] um tanto falso e exageradamente sentimental. Sua popularidade chega às vezes a me deixar constrangido" (VERÍSSIMO, 2005, p. 17). Contudo, há de se reconhecer que o romance reflete um aspecto social importante da época, a ditadura getulista, e reivindica um "socialismo humanista" proposto, de modo bastante claro, nas cartas de Olívia dirigidas a Eugênio. Além disso, o romance possui forte teor psicológico que permite um aprofundamento da narrativa apresentada. 


\title{
SACRILEGENS

\subsection{Eugênio e Olívia}

O romance narra a trajetória existencial de Eugênio, seu mundo circundante e seus dilemas interiores. Érico Veríssimo apresenta o personagem em plena crise de valores e crenças, com desejo de constituir-se enquanto indivíduo (BARROS, 2002). A primeira crise surge quando o papel social atribuído a ele não corresponde aos seus anseios mais profundos, lançando-o a uma busca de sentido para vida. Essa busca se inicia quando, ainda em sua infância, imagina Deus:

\begin{abstract}
Naquela noite Eugênio foi para a cama, impressionado. Rezou o seu padrenosso imaginando que Deus, o Kaiser e o Destino eram uma e a mesma pessoa. Os três eram poderosos, invisíveis e impiedosos. Deus era dono do mundo. O kaiser queria vencer a Europa inteira. O Destino era o culpado de todas as coisas ruins que aconteciam no mundo. (VERÍSSIMO, 2005, p. 34)
\end{abstract}

De família pobre, Eugênio não via em seu pai mais que "[...] um homem calado e murcho, envelhecido antes dos quarenta" (VERÍSSIMO, 2005, p. 26), que vivia fugindo dos credores.

Eugênio tinha uma grande pena do pai, mas não conseguia amá-lo. Sabia que os filhos devem amar aos pais. A professora falava na aula em "amor filial" contava histórias, dava exemplos. Mas, por mais que se esforçasse, Eugênio não lograva ir além da piedade. Tinha pena do pai, isso sim. Porque ele tossia, porque suspirava, porque se lamentava, porque se chamava Angelo. Angelo é nome de gente infeliz, nome de assassinado. (VERÍSSIMO, 2005, p. 26).

Não aceitava essa realidade, e fez da faculdade de medicina e ambição pelo dinheiro seu projeto, o único que poderia conferir sentido à sua vida. Na formatura do curso de medicina encontrou Olívia. Olívia era a única mulher da turma e formara-se também com sacrifício. Dali em diante estreitaram-se os laços, mas não a ponto de fazê-lo desistir da ideia de se casar com Eunice, mulher rica e atraente, filha de um grande empresário.

Contemplava Olívia. O luar lhe batia em cheio no rosto. Ela era bela, duma beleza que nada tinha de agressivo, mas que jazia escondida com um tesouro; era serena e possuía algo que fazia pensar nas coisas eternas e imutáveis. Por que ele não a amava mais? Por que não abandonava Eunice e tudo mais para se entregar inteiro a Olívia? (VERÍSSIMO, 2005, p. 131)

Para justificar sua decisão disse à Olivia: 


\section{SACRILEGENS

- Um amigo meu costumava dizer que a vida é como uma travessia transatlântica...Os passageiros são das mais variadas espécies. Uns passam a viagem a se preparar para o desembarque no porto de seu destino e desprezam as festas de bordo, o simples prazer de viajar. Outros não sabem do seu destino, não têm nenhuma esperança no porto de chegada e procuram passar da melhor maneira possível a travessia. Este é o meu caso. Tu sabes que em vão eu tenho procurado Deus. Ainda há pouco me lembrei duma noite de minha vida, há quinze anos. Eu pedi a Deus que me mandasse uma bola de futebol. Em vão esperei o milagre. Foi uma tolice de menino, eu sei, mas depois outras coisas pedi e esperei. Nada. Por último já me contentava com a revelação da simples existência desse Deus. Ainda nada! Não creio na outra vida. Quero fazer uma viagem agradável. E de certo modo me recuso a viajar em terceira classe...Tu vês que estou tentando passar para a primeira... (VERÍSSIMO, 2005, p. 133)

Nesse primeiro momento Eugênio é conduzido pelo desejo de ser aceito, o que o impede de viver de maneira autêntica. Embora a presença de Olívia fosse um prelúdio para que Eugênio saísse da condição de indivíduo coisificado para a condição de indivíduo autônomo e consciente de si, sujeito de suas próprias decisões, somente diante da sua ausência é que o personagem se movimenta em direção à essa transformação.

\subsection{Cartas: transformação e esperança}

Olívia, em sua última carta, escrita momentos antes de morrer, se apropria de um dos trechos do Sermão da Montanha, no qual estão dispostos os princípios práticos da vida cristã, propondo a Eugênio reconciliação com Deus e com os homens. Olívia concebe a religiosidade não como uma vivência mística individual, mas como uma experiência coletiva, que busca integrar o outro (BESSA, 2000). Ela apresenta a Eugênio um Deus diferente daquele conhecido na sua infância: um Deus punitivo e estático.

Uma noite me disseste que Deus não existia porque em mais de vinte anos de vida não $\mathrm{O}$ pudeste encontrar. Pois que até nisso se manifesta a magia de Deus. Um ser que existe nas é invisível para uns mal e mal perceptível para outros e duma nitidez maravilhosa para os que nasceram simples ou para os que adquiriram simplicidade por meio do sofrimento ou duma funda compreensão da vida (VERÍSSIMO, 2005, p. 153).

Apropriando-nos da teologia de Paul Tillich, Eugênio é encorajado por Olívia a perceber o "Deus que aparece quando Deus desapareceu na ansiedade da dúvida" (TILLICH, 1977, p. 146). A partir disso, se inicia um novo começo na vida de Eugênio, direcionando-o para uma nova forma de experimentar as situações que lhe 


\section{SACRILEGENS

são apresentadas. Enquanto o discurso religioso transmitido pela religião institucional não possibilita a Eugênio um autoconhecimento autêntico, o discurso de Olívia o confronta no mais íntimo da sua existência. Através de uma noção religiosa baseada na participação do indivíduo na coletividade humana e na natureza de Deus (BESSA, 2000), ele alcança alguma compreensão de um possível sentido para a existência. Rubem Alves ao falar da "morte de Deus" afirma que a consciência de Deus como objeto se transforma em esperança (1987). Deus enquanto símbolo da esperança é aquele que motiva o homem a ser de uma forma diferente diante do mundo. Não importa mais o que se fala sobre Deus, mas sim como se vive no mundo recebido com dádiva de Deus. É essa a concepção de Deus que encontramos nas cartas de Olívia, que mesmo experimentando o que Tillich chama de ameaça do nãoser, este que se apresenta de modo absoluto na ameaça da morte, vive seus últimos instantes serenamente e corajosamente nestas tensões e descobre, enfim, sua unidade última nas profundezas da própria alma. Encontramos nela, e depois em Eugênio ao se esforçar na criação da filha que Olívia lhe dera, a coragem de ser, isto é, "a autoafirmação a despeito daquilo que tende a impedir o eu de se afirmar" (TILLICH, 1977, p. 25), é estar apoderado pela aceitação da aceitação.

\section{Conclusão}

A relação entre literatura e religião, a partir do método teo-antropológico, proporciona a possibilidade de análise de um objeto que não pode ser analisado somente pela literatura ou pela teologia. A relação entre as áreas faz com que possamos interpretar a questão de Deus de uma forma muito própria e dinâmica, dado a facticidade da história humana. Nesse sentido, possibilita novos estudos que se distanciam de uma análise teológica eclesial enrijecida e, muitas vezes, obsoleta para os nossos tempos. Se assumimos a impossibilidade da apreensão conceitual sobre Deus, a sua inefabilidade e impossibilidade de um conhecimento sistemático, então assumimos a sua revelação na experiência humana, que se dá de forma contínua, mas sempre diferente de acordo com cada experiência. Desse modo, a revelação é inesgotável e descobrimos de forma parcial, somente a partir de aproximações referente à experiência, uma das infinitas possibilidades da manifestação de Deus. Portanto, ao analisarmos a obra de Hemingway e de Érico Veríssimo, podemos interpretar como a questão religiosa se manifesta nessas obras 


\section{SACRILEGENS \\ Revista Discente do Programa de

no interior de um determinado contexto. Se ficássemos enrijecidos em uma leitura eclesial e dogmática, perderíamos a revelação que está sempre presente em nossas experiências. É esta peculiaridade e singularidade de se pensar a religião, que buscamos pensá-la nos elementos dos romances em ambos os autores, que podem estar presentes em muitos outros autores, o que demonstra a riqueza do campo de investigação. No entanto, a escolha realizada não se mostra como única, mas como possível.

\section{Referências}

AGUIAR, Luiz Antonio. Introdução. In: HEMINGWAY, Ernest. Adeus às Armas.8 ed.Rio de Janeiro: Bertrand Brasil, 2013, p. 7-9.

ALVES, RUBEM. Da Esperança. São Paulo: Papirus, 1987.

BINGEMER, Maria Clara. Teologia e Literatura: afinidades e segredos compartilhados. Petrópolis, RJ: Vozes; Rio de Janeiro: Editora PUC, 2015.

BESSA, Daniela Borja. O discurso religioso em Olhai os Lírios do Campo. Belo Horizonte: UFMG, 2000, 140 p. Dissertação (Mestrado em Letras). Programa de PósGraduação em Letras: Estudos Literários da Universidade Federal de Minas Gerais, Minas Gerais, 2000.

BESSA, Daniela Borja. O discurso religioso em Olhai os Lírios do Campo. Belo Horizonte: revista teologia prática, v.1, n.1, p. 31-37, 2002.

CAPELLI, Márcio Aló Lopes. Por uma teologia ficcional: a (des)construção teológica na reescritura bíblica de José Saramago.Rio de Janeiro: PUC-RIO, 2017, 326 p. Tese (Doutorado em Teologia). Programa de Pós-graduação em Teologia. Pontifícia Universidade Católica do Rio de Janeiro, Rio de Janeiro, 2017.

CIORAN, Emil Michel. Silogismos da amargura.Rio de Janeiro: Editora Rocco, 2011.

HEIDEGGER, M. A questão da técnica . Scientiae Studia, [S. 1.], v. 5, n. 3, p. 375-398, 2007. DOI: 10.1590/S1678-31662007000300006. Disponível em: https://www.revistas.usp.br/ss/article/view/11117. Acesso em: 13 dez. 2020.

HEMINGWAY, Ernest. Adeus às Armas. 8 ed.Rio de Janeiro: Bertrand Brasil, 2013 . 


\section{SACRILEGENS}

SILVEIRA, Karina Masci. Teopoética - um campo de pesquisa para cientistas da religião? São Paulo: revista último andar, n. 34, p. 138-165, 2019.

SOARES, Afonso Maria Ligorio. A teologia em diálogo com a ciência da religião. In: USARSKI, Frank (Org.). São Paulo: Paulinas, 2002.

STEWART, Jon. Soren Kierkegaard: subjetividade, ironia e a crise da modernidade. Tradução Humberto Araújo Quaglio de Souza. Petrópolis: Vozes, 2017 .

TILLICH, Paul. A coragem de ser. 3. ed. Rio de Janeiro, RJ: Paz e Terra, 1977.

VERÍSSIMO, Érico. Olhais os Lírios do Campo. São Paulo: Companhia das Letras, 2005.

VILLAS BOAS, Alex. O Método Teo-antropológico no diálogo entre Teologia e Literatura em Antônio Manzatto. Revista de Cultura Teológica, [S.l.], n. 95, p. 24-48, maio 2020. ISSN 2317-4307. Disponível em: <http://revistas.pucsp.br/culturateo/article/view/46974>. Acesso em: 18 jun. 2020. doi:https://doi.org/10.23925/rct.i95.46974. 